Article

\title{
Green Conversion of Coal Fly Ash into Soil Conditioner: Technological Principle and Process Development
}

\author{
Huidong Liu *, Yongfeng Xiao * and Xiaolin Jiang \\ National Institute of Clean-and-Low-Carbon Energy, Beijing 102211, China; 18810537791@163.com \\ * Correspondence: we510865758@126.com (H.L.); 20022126@chnenergy.com.cn (Y.X.); \\ Tel.: +86-010-57336190 (H.L.)
}

\begin{abstract}
White mud is residue discharged during the acid method in the aluminum extraction process from coal fly ash, and this material is harmful to the environment. The implementation of an environmentally friendly and valuable way to use white mud is a key factor restricting the commercial application of the acid method in the fly ash alumina extraction technology. An analysis of white mud revealed the following: (1) it was highly enriched in $\mathrm{SiO}_{2}$ (70-80\%) while concentrations of acid-soluble elements, such as $\mathrm{Na}, \mathrm{Al}$, and $\mathrm{Fe}$, and some hazardous heavy metals, including $\mathrm{Pb}$ and $\mathrm{Cr}$, were significantly lower than raw fly ash; (2) approximately $80 \%$ of $\mathrm{SiO}_{2}$ had relatively high reaction activity because of the foregoing Al-extraction treatment. Through an ingenious green chemical process, the complete conversion of white mud into silicon-calcium fertilizer (SCF) was achieved under very mild reaction conditions (approximately $100{ }^{\circ} \mathrm{C}$ and atmospheric pressure). Waste liquor was totally recycled, and no secondary solid waste was generated. The SCF had an available silicon content (ASC) of 35\%, significantly higher than the commercial standard (20\%). Converting them into soil conditioners or ecological remediation materials with the lowest possible energy consumption and secondary pollution may be the most promising approach for the future disposal of aluminosilicate industrial solid wastes.
\end{abstract}

Citation: Liu, H.; Xiao, Y.; Jiang, X. Green Conversion of Coal Fly Ash into Soil Conditioner: Technological Principle and Process Development. Minerals 2022, 12, 276. https:// doi.org/10.3390/min12030276

Academic Editors: Xiaomei Wang, Alexandra Guedes, Shuqin Liu and Lei Zhao

Received: 16 January 2022

Accepted: 17 February 2022

Published: 22 February 2022

Publisher's Note: MDPI stays neutral with regard to jurisdictional claims in published maps and institutional affiliations.

Copyright: (c) 2022 by the authors Licensee MDPI, Basel, Switzerland. This article is an open access article distributed under the terms and conditions of the Creative Commons Attribution (CC BY) license (https:// creativecommons.org/licenses/by/ $4.0 /)$.

Keywords: fly ash utilization; heavy metal elements; available silicon; one-step hydrothermal activation; soil remediation

\section{Introduction}

High alumina coal and coal combustion fly ash in the Zhungeer coal basin in China, a "unique polymetallic artificial deposit," has attracted increasing attention [1-5]. The amount of aluminum in this high-Al coal and fly ash is estimated to be as high as 10 billion tons of $\mathrm{Al}_{2} \mathrm{O}_{3}$. Development of high- $\mathrm{Al}$ fly ash is of great importance in reducing China's excessive dependence on bauxite resource importing.

Attempts to recover aluminum from fly ash can be traced back to the 1950s [6]. Recovery technologies for aluminum from fly ash include the Bayer method (1) [7], a hightemperature chlorination process (2) [8], and the acid-leaching method (3) [9]. So far, many researchers and engineers have made improvements to these three systems [10,11]. Using the Zhungeer high-Al circulating fluidized bed fly ash as a raw material, the China National Energy Group developed and successfully applied the enhanced one-step hydrochloricacid-leaching method to produce a metallurgical grade alumina product; the recovery rate of aluminum is up to $85 \%$ [12]. More importantly, volume of the secondary solid waste (commonly known as white mud) discharge is only one-third of that generated by the alkali method. A fly ash alumina extraction (FAAE) semi-industrial plant (125 kt of $\mathrm{Al}_{2} \mathrm{O}_{3}$, annually) is currently in the design and construction stage. Future progress of acid corrosion resistance technologies will ensure $\mathrm{HCl}$ acid leaching as the most promising method for FAAE. Nevertheless, when this plant begins production, approximately $180 \mathrm{kt}$ of HCl-bearing white mud will be generated, requiring safe disposal. China is currently 
searching for cleaner industrial production and a more efficient model for economic growth. Therefore, environmentally friendly and valuable utilization of white mud is a key factor restricting the commercial application of the acid method in FAAE technology.

A promising strategy has been proposed to transform harmful white mud into an ecological restoration material: silicon-calcium fertilizer (SCF). Traditional chemical fertilizers are predominantly used to supplement major nutritional elements, such as nitrogen, phosphorus, and potas-um; this results in a deficiency in medium or micro elements, especially the available silicon. The effects of silicon nutrients on improving soil structure, passivating heavy metals, and increasing yield and quality of agricultural products have been widely confirmed [13-17]. In fact, the use of silicon as a nutrient has been widely studied in tropical regions and for rice production around the world, specifically in India [18,19], Japan [20], and China [21,22]. Cheap and efficient silicon fertilizer products are urgently needed in the market. Currently, approximately $50 \%$ of paddy rice soils in China are Si-deficient; the annual shortfall in demand for silicon fertilizer in the Chinese market is estimated to be up to 40 million tons, offering tremendous space for the disposal demand of white mud or other similar solid wastes.

Research on the production and application of SCF or soil conditioner directly using fly ash as a raw material has been in progress and has become a hot spot. Silica gels obtained from coal ash by the alkali-acid $(\mathrm{NaOH}-\mathrm{HCl})$ chemical method were used to make SCF, with available silicon content (ASC) values ranging around 30\% [23]. After mixing with the equal mole $\mathrm{Ca}(\mathrm{OH})_{2}$ powder and hydrothermally reacting $\left(200{ }^{\circ} \mathrm{C}\right)$ in $0.6 \mathrm{~mol} / \mathrm{L}$ $\mathrm{KOH}$ solution for $5 \mathrm{~h}$, fly ash can be transformed into a soil conditioner product with an ASC $=35 \%$ [24]. However, the suspicion of ecological safety caused by excessive heavy metal content in fly ash has never disappeared $[25,26]$. This is also the key factor restricting the combination of fly ash utilization and soil remediation. On the other hand, how to significantly reduce the cost of fly ash SCF production, mainly the energy consumption, is the primary technical direction, which determines if this technology can be commercialized.

This work aims to convert white mud into a high-quality SCF product through an innovative green process that is expected to provide a feasible approach for the economically sustainable and ecological application of the coal fly ash resource.

\section{Materials and Methods}

\subsection{Materials}

The raw materials used in this study were collected from the FAAE demonstration plant in Zhungeer, Inner Mongolia, China. After drying, the ash yield elements and mineral composition of the white mud samples were determined by $X$-ray fluorescence spectrometry (XRF, ZSX Primus, Rigaku, Japan) and X-ray diffraction (XRD, D8 ADVANCE, Bruker, Germany). As shown in Table 1, white mud is predominately composed of $\mathrm{SiO}_{2}(78.7 \%)$, $\mathrm{Al}_{2} \mathrm{O}_{3}(13.4 \%)$, and $\mathrm{TiO}_{2}(5.2 \%)$. Concentrations of acid-soluble elements, such as $\mathrm{Na}, \mathrm{Al}$, and some heavy metals, are much lower than that of the parent material (fly ash) because of the acid-leaching process. Enrichment of the $\mathrm{SiO}_{2}$ and dilution of the $\mathrm{Al}_{2} \mathrm{O}_{3}$ facilitates the production of high-quality SCF. This is also why traditional SCF manufacturing would previously select high-cost feldspar ore $\left(\mathrm{SiO}_{2}=64.7 \%, \mathrm{Al}_{2} \mathrm{O}_{3}=18.4 \%\right)$ as a raw material rather than clay minerals (e.g., kaolinite, $\mathrm{SiO}_{2}=46.5 \%, \mathrm{Al}_{2} \mathrm{O}_{3}=39.5 \%$ ) even though clay materials are much cheaper and more readily available.

Table 1. Elemental composition (ash base) of white mud and the alkali-leaching desiliconized white mud $(\%)$.

\begin{tabular}{ccccccccccc}
\hline & $\mathrm{Al}_{2} \mathbf{O}_{\mathbf{3}}$ & $\mathbf{S i O}_{2}$ & $\mathbf{P}_{\mathbf{2}} \mathbf{O}_{\mathbf{5}}$ & $\mathbf{S O}_{3}$ & $\mathbf{K}_{\mathbf{2}} \mathbf{O}$ & $\mathbf{N a}_{\mathbf{2}} \mathbf{O}$ & $\mathbf{C a O}$ & $\mathrm{TiO}_{2}$ & $\mathbf{F e}_{2} \mathbf{O}_{\mathbf{3}}$ & $\mathrm{ZrO}_{2}$ \\
\hline High-Al fly ash & 52.5 & 38.1 & 0.31 & 0.64 & 0.55 & 0.06 & 2.11 & 2.81 & 2.10 & 0.18 \\
White mud & 13.4 & 78.7 & 0.14 & 0.35 & 0.16 & bdl ${ }^{1}$ & 0.37 & 5.2 & 0.45 & 0.29 \\
Desiliconized white mud [27-29] & 56.7 & 23.2 & 0.1 & 0.67 & 0.12 & 3.44 & 0.95 & 11.7 & 1.71 & 0.48 \\
\hline
\end{tabular}

\footnotetext{
${ }^{1}$ below the minimum detection limit.
} 
Available silicon content (ASC) in soil is drastically different from the unavailable silicon that cannot be absorbed and used by crops; ASC is the most critical indicator of silicon fertilizer. The commercial standard for silicon fertilizer in China is ASC $\geq 20 \mathrm{wt} \%$. A higher ASC value demands a higher product selling price. Therefore, the key to preparing silicon fertilizer is converting unavailable silicon into the available form while minimizing the cost of materials and energy consumption.

Previous white mud desiliconization studies [27-29] conducted by our team indicated that more than $80 \%$ of the silicon in white mud is extractable by $\mathrm{NaOH}$ alkali leaching, and we referred to this portion of silicon as active silicon. In combination with the X-ray diffraction (XRD) analysis (Figure 1), active silicon is inferred to come from amorphous glass; this percentage can be characterized by the integrated intensity of the dispersion peak existing in the $2 \theta=15^{\circ}-35^{\circ}$ section of the XRD spectral line.

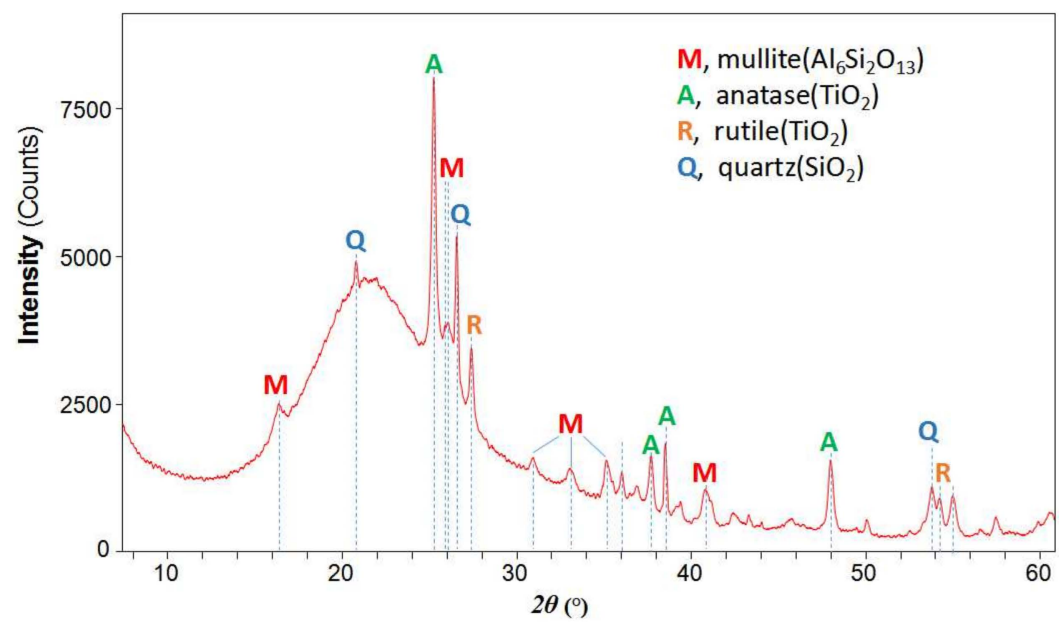

Figure 1. Mineral composition of white mud based on XRD analysis.

In addition to amorphous glass, the mineral composition of white mud includes mullite, quartz, anatase, and rutile. Carrier minerals for $\mathrm{Al}_{2} \mathrm{O}_{3}$ and $\mathrm{SiO}_{2}$ are mainly mullite $\left(3 \mathrm{Al}_{2} \mathrm{O}_{3}-2 \mathrm{SiO}_{2}\right)$ and quartz $\left(\mathrm{SiO}_{2}\right)$ while the carrier minerals for $\mathrm{TiO}_{2}$ are anatase and rutile. These crystal minerals all have a highly stable crystal structure, which ensures they can be preserved and enriched after high-temperature acid leaching.

These minerals also show no reaction in the alkali-leaching desiliconization experiments mentioned above. In contrast to the active silicon in amorphous glass, the silicon in crystal minerals is referred to as inactive silicon. The theoretical energy consumption for the conversion from active silicon to available silicon is significantly lower than that of inactive silicon to available silicon. In this study of a low-cost production method of SCF from white mud, only the active silicon will be activated and converted while inactive silicon will not participate in the activation reaction.

\subsection{Technique Principle and Methods of Silicon Activation}

The current SCF production technology uses the calcining activation method $\left(1300^{\circ} \mathrm{C}\right.$ heating for $30 \mathrm{~min}$ ) of potash feldspar. Research on reducing the costs of raw materials and energy consumption has not produced significant improvements. Some researchers have attempted the autoclaved activation method to produce silicon-calcium-potassium fertilizer, with an acceptable activation efficiency. For example, Liu Jianming et al. [30-32] successfully produced $\mathrm{Si}-\mathrm{Ca}-\mathrm{K}$ fertilizer with ASC $>20 \%$ from potassium feldspar and $\mathrm{Ca}(\mathrm{OH})_{2}$ powder as raw materials by autoclave activation at $190{ }^{\circ} \mathrm{C}$ for $8-12 \mathrm{~h}$ in a closed vessel. However, the reaction pressure could reach $1.25 \mathrm{MPa}$, leading to a considerable increase in costs for equipment investment and production operation.

Luo and $\mathrm{Wu}$ (2021, Preprint) published their work on the preparation of silicon fertilizer using the residue from alumina extraction of coal fly ash by decomposing the main 
mineral phase $\left[\mathrm{NaCaHSO}_{4}\right]$ under an alkali hydrothermal environment $\left(\mathrm{Na}_{2} \mathrm{O}=30 \mathrm{~g} / \mathrm{L}\right.$, $\mathrm{L} / \mathrm{S}=25,150{ }^{\circ} \mathrm{C} / 4 \mathrm{~h}$ ) [33]. Although its topic ASC value reached $28.75 \%$, the high temperature and pressure operating conditions and a high L/S may still not be suitable for the industrial production.

Based on the characterization and experimental analysis mentioned above, efficient conversion of active silicon in white mud into available silicon can be realized under a mild hydrothermal reaction situation (e.g., approximately $100{ }^{\circ} \mathrm{C}$, at atmospheric pressure; $\left.\mathrm{SiO}_{2}+2 \mathrm{NaOH}+(n-1) \mathrm{H}_{2} \mathrm{O} \rightarrow \mathrm{Na}_{2} \mathrm{SiO}_{3} \cdot n \mathrm{H}_{2} \mathrm{O}\right)$. However, this process could cause excess sodium and high $\mathrm{pH}$ in the final product; the application of this product to soil would increase the risk of salinization and alkalization. Additionally, the reaction product is too viscous to be filtered and dried because of the presence of water glass $\left(\mathrm{Na}_{2} \mathrm{SiO}_{3} \cdot n \mathrm{H}_{2} \mathrm{O}\right)$.

Calcium is an essential nutrient for crops. $\mathrm{Ca}(\mathrm{OH})_{2}$ was evaluated as a substitute for $\mathrm{NaOH}$ as an activator. Unfortunately, no acceptable activation efficiency could be achieved under atmospheric pressure using $\mathrm{Ca}(\mathrm{OH})_{2}$ even when the reaction temperature was increased above $160{ }^{\circ} \mathrm{C}$. The reactive activity of $\mathrm{Ca}$ is much lower than $\mathrm{Na}$, which is why the calcination temperature and energy consumption cannot be significantly reduced with a calcium-based activator.

To solve the above technical challenge, an innovative technique principle for silicon activation was developed:

1. In an atmospheric pressure hydrothermal environment, $\mathrm{NaOH}$ was first reacted with the active silicon in white mud (Equation (1)).

$$
\mathrm{SiO}_{2}+\underline{2 \mathrm{NaOH}}+(n-1) \mathrm{H}_{2} \mathrm{O} \rightarrow \mathrm{Na}_{2} \mathrm{SiO}_{3} \cdot n \mathrm{H}_{2} \mathrm{O}
$$

2. $\mathrm{CaO}$ powder was synchronously added to the reaction system and continued to react with $\mathrm{Na}_{2} \mathrm{SiO}_{3} \cdot \mathrm{H}_{2} \mathrm{O}$ produced in Step 1 .

$$
\mathrm{Na}_{2} \mathrm{SiO}_{3} \cdot n \mathrm{H}_{2} \mathrm{O}+\mathrm{CaO} \rightarrow \mathrm{CaSiO}_{3} \cdot n \mathrm{H}_{2} \mathrm{O} \downarrow+\underline{2 \mathrm{NaOH}}
$$

3. $\mathrm{NaOH}$ participated in the whole reaction as a catalyst and was not consumed (Equation (2)). The $\mathrm{NaOH}$ solution was easily recovered and recycled in the next round of the reaction, ensuring the minimization of alkali cost and the alkalinity residue in the final product. Therefore, Equations (1) and (2) can be merged into a single equation (Equation (3)).

$$
\mathrm{SiO}_{2}+\mathrm{CaO}+n \mathrm{H}_{2} \mathrm{O} \stackrel{\mathrm{NaOH}}{\rightarrow} \mathrm{CaSiO}_{3} \cdot n \mathrm{H}_{2} \mathrm{O} \downarrow
$$

Based on this new reaction principle for silicon activation, white mud SCF can be obtained through a one-step hydrothermal activation procedure, shown in Figure 2.

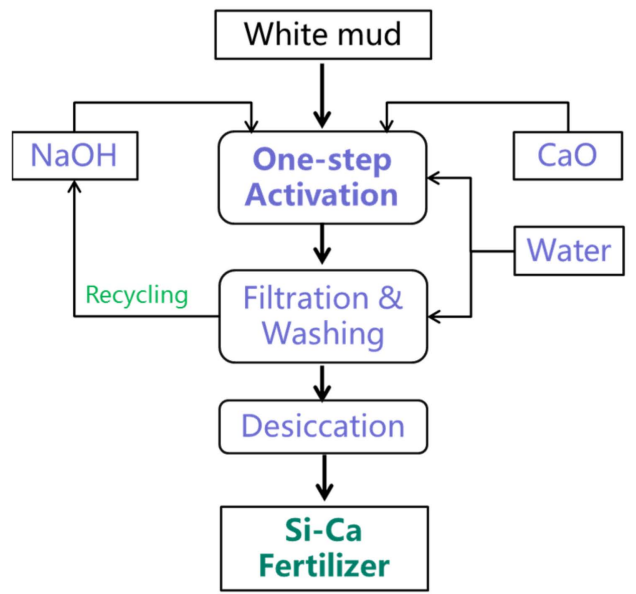

Figure 2. Technical process for the preparation of white-mud-based SCF. 
In order to rapidly define the appropriate range of reaction conditions, orthogonal experiments $\left(\mathrm{L}_{9} 3^{4}\right)$ were carried out by focusing on four factors (three levels for each factor): activating temperature $\left(T=90^{\circ} \mathrm{C}, 100{ }^{\circ} \mathrm{C}, 120^{\circ} \mathrm{C}\right)$, reaction time $(t=2 \mathrm{~h}, 3 \mathrm{~h}, 4 \mathrm{~h})$, activator type $(A T=\mathrm{I}, \mathrm{II}, \mathrm{III})$, and the mass ratio of liquid (water) to solid (white mud) $(L / S=6,10$, 20). Activator Type I, II, and III represent different ratios of $\mathrm{Ca}-\mathrm{Mg}-\mathrm{Na}-\mathrm{K}$, respectively.

\subsection{Analysis Method for SCF Product}

A field emission scanning electron microscope (SEM, Nova NanoSEM, FEI, USA) was used to obtain information about the micromorphological information of the white mud SCF product. A laser particle size analyzer (Master sizer 2000, Malvin Instrument, Cambridge, UK) was used to analyze the overall fineness and particle size distribution of the SCF.

The ASC and available CaO content (ACC) for the SCF samples were determined using the Chinese Standard NY/T 2272, which has been described in detail by Hu et al. (2015) [34]. The sample was mixed with a $150 \times(\mathrm{mL} / \mathrm{g}) \mathrm{HCl}$ solution $(0.5 \mathrm{~mol} / \mathrm{L})$ and oscillated at $30{ }^{\circ} \mathrm{C}$ for $80 \mathrm{~min}$. After this reaction, the filtrate was obtained to determine the dissolved silica content. The percentage of the soluble $\mathrm{SiO}_{2}(\mathrm{CaO})$ mass of the total sample mass was equivalent to the ASC (ACC) value.

\section{Results}

\subsection{Optimal Parameters for the Hydrothermal Activation}

An extremum difference analysis of the orthogonal experiments data, as listed in Table 2, indicated that the degree of influence of the hydrothermal activation factors on ASC occur in descending order: $A T>T>L / S>t$. The proper composition of the activator is the most important factor for effective silicon activation. Not surprisingly, reaction temperature and time also played crucial roles in hydrothermal systems. However, a delicate balance of temperature and time is clearly needed. An inadequate activation energy input (e.g., $T=90^{\circ} \mathrm{C}, t=2 \mathrm{~h}$ ) led to an insufficient reaction (Equation (3), Section 2.2), which was easily understood, but increasing the reaction temperature (e.g., $T=120^{\circ} \mathrm{C}$ ) or time (e.g., $t=4 \mathrm{~h}$ ) further brought about a decrease instead of a rise in ASC. That is because the hydrothermal activation of amorphous $\mathrm{SiO}_{2}$ in fly ash or similar heat-treated aluminosilicate solid waste (including white mud) partially overlaps with the reaction conditions for hydrothermal crystallization of zeolites; as the activation conditions shift toward crystallization conditions, the elements $\mathrm{Al}$ and $\mathrm{Na}$, instead of $\mathrm{Ca}$, prefer to rebind with the activated $\mathrm{Si}$ released from the amorphous glass, resulting in an excessive generation of zeolites [35-37] (Figure 3A vs. Figure $3 \mathrm{~B})$. The occurrence of this side reaction decreased both the ASC value of the final products and the recovery or cycle rate of $\mathrm{Na}$. A smaller $L / S$ in industrial production would increase production efficiency and reduce pressure of wastewater treatment; therefore, $L / S=10$ was also considered acceptable since the mean ASC value $\left(K_{i}\right)$ of $L / S=10(26.58 \%)$ was only slightly lower than $L / S=20(27.87 \%)$.



Figure 3. SEM images of the white-mud-based SCF products: (A) No. 6 sample with lamellar structure; (B) No. 9 sample with excessive zeolite crystals. 
Table 2. Conditions and test results from the hydrothermal activation $\mathrm{L}_{9} 3^{4}$ orthogonal experiments.

\begin{tabular}{cccccc}
\hline No. & Temp. $/^{\circ} \mathbf{C}$ & Time/h & Activator Type & L/S & ASC/\% \\
\hline 1 & 90 & 4 & I & 6 & 27.18 \\
2 & 90 & 2 & II & 10 & 11.94 \\
3 & 90 & 3 & III & 20 & 28.38 \\
4 & 100 & 4 & II & 20 & 20.50 \\
5 & 100 & 2 & III & 6 & 29.44 \\
6 & 100 & 3 & I & 10 & 37.86 \\
7 & 120 & 4 & III & 10 & 29.93 \\
8 & 120 & 2 & I & 20 & 34.73 \\
9 & 120 & 3 & II & 6 & 13.88 \\
$K_{1}$ & 22.50 & 25.71 & 33.26 & 23.5 & \\
$K_{2}$ & 29.27 & 25.37 & 15.44 & 26.58 & \\
$K_{3}$ & 26.18 & 26.71 & 29.25 & 27.87 & \\
$R=\max \left\{K_{i}\right\}-\min \left\{K_{i}\right\}$ & 6.767 & 1.337 & 17.817 & 4.370 & \\
\hline
\end{tabular}

The effect curve (Figure 4) of each factor based on the mean value of each experimental level was drawn to make a visual analysis for finding the best level. Eventually, the gram-scale optimal parameters were determined as $\left(T=100{ }^{\circ} \mathrm{C}, t=3 \mathrm{~h}, A T=\mathrm{I}\right.$, and $L / S=10-20$ ), which happened to appear in the No. 6 experiment listed in Table 2. Its ASC value reached $37.86 \%$, much higher than the commercial standard for silicon fertilizer in China (ASC $\geq 20 \%$ ). The ACC value reached $34.79 \%$ for the same sample. Therefore, high-performance SCF products were produced by this process.

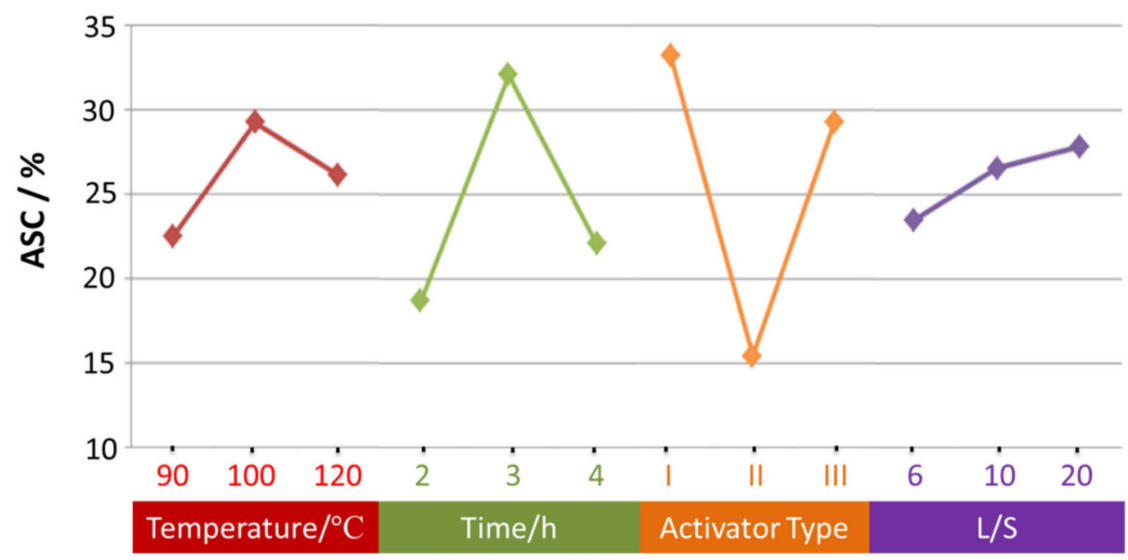

Figure 4. Effect curves of the $\mathrm{L}_{9} 3^{4}$ orthogonal experiments of white mud SCF production.

Aluminum and sodium are two unfavorable factors for SCF because these two elements are already present in excess in the soil. In this study, soluble $\mathrm{Al}_{2} \mathrm{O}_{3}$ and soluble $\mathrm{Na}_{2} \mathrm{O}$ in products prepared under diverse experimental conditions were also monitored (Table 2).

Single-factor experiments were further carried out around the optimal parameters. During the process of actual operations, it was discovered that the insufficient addition of $\mathrm{Ca}$ resulted in the presence of $\mathrm{Na}_{2} \mathrm{SiO}_{3}$ (Equation (1), Section 2.2), making it difficult to execute the filtration, washing, and drying, and caused filtration losses of $\mathrm{Si}$ and $\mathrm{Na}$. Although $\mathrm{Ca}$ is a nutrient for crops, a superabundant $\mathrm{Ca}$ addition will dilute the ASC index of the SCF product. Superfluous $\mathrm{Ca}(\mathrm{OH})_{2}$ would also cause an unwished high $\mathrm{pH}$ value of the final product.

\subsection{Kilogram-Scale Verification Experiments for SCF Production}

Based on the optimized process parameters obtained from the above gram-scale experiments, SCF preparation experiments at the kilogram scale were carried out using a 
$5 \mathrm{~L}$ double-layer glass reactor. Through several additional experiments, the reaction time and the L/S value were adjusted to $3.5 \mathrm{~h}$ and 8 , respectively. To achieve the reuse of alkali and water to save material costs and reduce secondary pollution, the produced waste lye from reaction Round I was collected and reused in Round II and again in Round III. During this process, almost no secondary solid waste was discharged.

As shown in Table 3, the ASC values of the SCF products from Rounds I to III vary from 35.05 to $37.60 \%$, almost meeting the best performance data achieved in the gram-scale experiments $(37.86 \%)$; the ASC value is also much higher than the commercial silicon fertilizer standard (20\%). The ACC values of three samples also exceed the commercial standard of $28 \%$.

Table 3. Technical Index of SCF products prepared from the kilogram-scale lye-cycle experiments.

\begin{tabular}{cccccccc}
\hline & & & & \multicolumn{3}{c}{ Heavy Metal Elements (ppm) } \\
\cline { 4 - 8 } & ASCl\% & ACC/\% & Cr & Cd & Pb & Hg & As \\
\hline Round I & 36.36 & 29.99 & 14.45 & 0.22 & 19.18 & 3.91 & 2.83 \\
Round II & 35.05 & 31.17 & 15.91 & 0.25 & 20.50 & 4.00 & 3.00 \\
Round III & 37.60 & 29.78 & 16.71 & 0.24 & 21.09 & 2.81 & 3.56 \\
Standard [38] & $\geq 20$ & $\geq 28$ & $\leq 500$ & $\leq 10$ & $\leq 200$ & $\leq 5$ & $\leq 50$ \\
\hline
\end{tabular}

The last remaining criteria to determine if the produced products could be used as commercial SCF was whether the heavy metals $(\mathrm{Pb}, \mathrm{Cr}, \mathrm{Cd}, \mathrm{Hg}$, As) exceeded the corresponding limits. The heavy metal contents of the three products are all below the required magnitude by the Chinese standard [38]. Therefore, the products are initially identified as an ecologically safe and high-performance SCF product.

\subsection{Detailed Characterization of the White Mud SCF}

The typical microtopography of SCF is a lamellar structure with low crystallinity (Figure 3A), with the chemical components of $\mathrm{Ca}-\mathrm{Si}-\mathrm{H}-\mathrm{O}$. White mud SCF possesses excellent fineness (Figure 5, Dv50 =17.9 $\mu \mathrm{m}$ ) and a microscopic porous structure, which contribute to the overall high-specific surface area and absorbability. These characteristics help in the conservation and slow release of nutrients and moisture and are also conducive to the adsorption and deactivation of heavy metals in soil. Porous, unburned carbon inside the SCF may also increase the specific area and adsorptive properties.

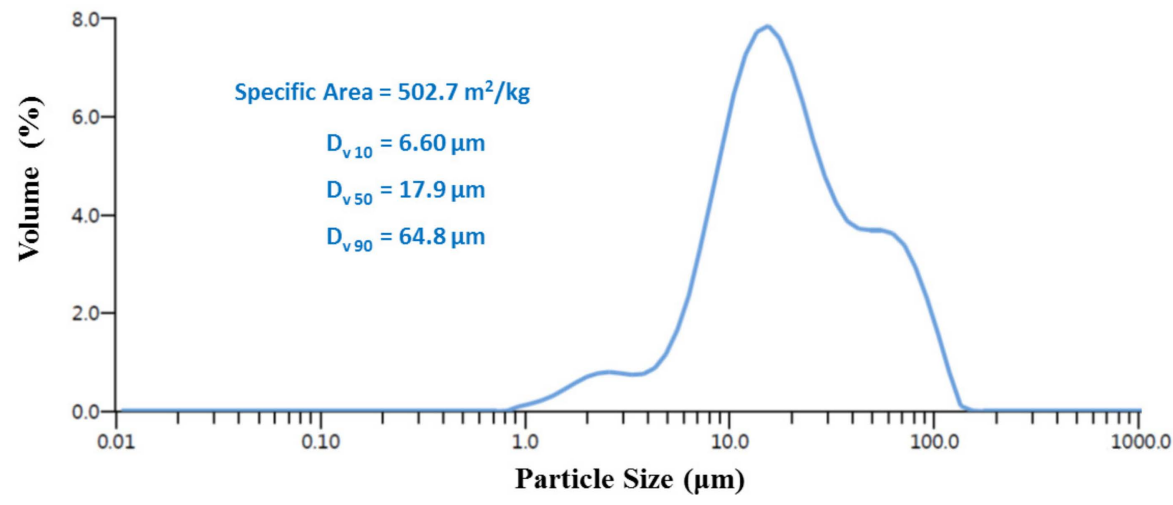

Figure 5. Laser particle size distribution of the white mud SCF product powder.

The cation exchange capacity $(\mathrm{CEC}, \mathrm{cmol} / \mathrm{kg}$ ) is the molar number of all exchangeable cations (i.e., $\mathrm{K}^{+}, \mathrm{Na}^{+}, \mathrm{Ca}^{2+}, \mathrm{NH}_{4}^{+}, \mathrm{H}^{+}, \mathrm{Al}^{3+}$ ) in the soil. A higher $\mathrm{CEC}$ value indicates that more nutrients can be preserved in the soil. The CEC is commonly used as a key index to evaluate soil fertility. Although there is no mandatory standard for the CEC in SCF or soil conditioner products, the soil's CEC index can be directly and effectively increased when the soil conditioner product has a significantly higher CEC. Therefore, the CEC levels of 
SCF samples produced in this experiment compared with those of commercial calcination products using the test method published by the China Environmental Industry Standard (HJ889-2017) for soil. Data (Table 4) indicated that our product had a significantly higher CEC than the purchased product.

Table 4. Cation exchange capacity (CEC) of SCF products produced by various activation methods.

\begin{tabular}{|c|c|c|c|}
\hline Samples & $\operatorname{ASC}(\%)$ & $\operatorname{ACC}(\%)$ & $\begin{array}{c}\text { CEC } \\
\text { (cmol/kg) }\end{array}$ \\
\hline White mud-hydrothermal-activated SCF & 37.6 & 29.8 & 38.26 \\
\hline $\begin{array}{l}\text { Potash feldspar-autoclave-activated SCF } \\
\text { (commercial product) }\end{array}$ & 20.0 & 25.0 & 45.0 \\
\hline $\begin{array}{l}\text { Potash feldspar-calcination-activated SCF } \\
\text { (commercial product) }\end{array}$ & 26.0 & 24.9 & 5.53 \\
\hline General Chinese farmland soil & - & - & $10-20$ \\
\hline
\end{tabular}

The CEC is also the main source of the soil buffering capacity for harmful $\mathrm{Na}^{+}, \mathrm{Al}^{3+}$, heavy metals, and $\mathrm{pH}[39,40]$. When the $\mathrm{CEC} \geq 20 \mathrm{cmol} / \mathrm{kg}$, soil has a stronger heavy metal antagonism ability. The CEC of general Chinese farmland soil varies from 10 to $20 \mathrm{cmol} / \mathrm{kg}$; at a value of CEC $\leq 5 \mathrm{cmol} / \mathrm{kg}$, the upper limit of soil heavy metal content is reduced by half (Chinese Soil Environmental Quality Standard, GB 15618-1995). SCF generated by the calcination method with a poor CEC $(5.53 \mathrm{cmol} / \mathrm{kg})$ does not show a direct improvement of the soil's CEC. In contrast, the hydrothermal SCF product with a significantly higher CEC level $(38.26 \mathrm{cmol} / \mathrm{kg})$ should have a higher potential to improve soil.

Soil is derived from the natural weathering of upper crust rocks; therefore, soil and rocks are homologous in terms of elemental composition. Coal is also a type of rock enriched in organic matter. Crushing and grinding, burning (thermal activation of crystal minerals), acid method alumina extraction (geological eluviation), and SCF production (alkali hydrothermal alteration) all simulate the natural processes of soil formation. Therefore, these processes follow the natural pathways for soil formation but at a higher rate. Therefore, it is understandable that the hydrothermal SCF products have comprehensive advantages. This technical solution could also be applicable to similar geological solid wastes, such as fly ash, coal gasification slag, and steel slag. Preliminary calculations indicate that the production cost of white mud SCF through the proposed atmosphericpressure and low-temperature hydrothermal activation method can be controlled at US $\$ 60$, approximately two-thirds the cost of existing technologies.

\section{Conclusions}

Some inherent superiority on the elemental and mineral composition of white mud, such as being Si-rich, ecologically safe from a heavy metal aspect and easily activated, were discovered and fully utilized in this work. An innovative, low temperature and atmospheric pressure hydrothermal activation process $\left(T=100^{\circ} \mathrm{C}, t=3.5 \mathrm{~h}, A T=\mathrm{I}\right.$, and $\left.L / S=8\right)$ on a kilogram scale was developed, with low energy consumption, low material cost, and highefficiency activation of silica. Experiments indicated that white mud can be $100 \%$ converted into a high-performance SCF product with good fineness (Dv50 $=17.9 \mu \mathrm{m}$ ), an abundant porous structure, and a high CEC $(38.26 \mathrm{cmol} / \mathrm{kg})$. In particular, the core quality index ASC can reach $35.05 \%-37.60 \%$, about $80 \%$ higher than the commercial silicon fertilizer standard (ASC $=20 \%$ ). All of these features would contribute to the actual effects of white mud SCF products, such as conservation, the slow release of nutrients and moisture, adsorption and fixation of heavy metals in soil, etc.

Conversion of industrial solid wastes into soil conditioners supports agricultural development and ecology preservation with minimal cost and may also provide a promising direction for the utilization of similar aluminosilicate industrial wastes (e.g., fly ash, coal gasification slag, coal gangue, alumina red mud) in the foreseeable future. 


\begin{abstract}
Author Contributions: Conceptualization, H.L.; methodology, H.L. and X.J.; investigation, X.J.; experiments design and execution, H.L.; sample characterization, Y.X.; writing-original draft preparation and editing, Y.X. and H.L. All authors have read and agreed to the published version of the manuscript.
\end{abstract}

Funding: This research was funded by the National Natural Science Foundation of China (42002196).

Institutional Review Board Statement: Not applicable.

Informed Consent Statement: Not applicable.

Data Availability Statement: Data sharing is not applicable to this article.

Acknowledgments: We are very grateful to three anonymous reviewers for their valuable comments that helped to improve our manuscript.

Conflicts of Interest: The authors declare no conflict of interest.

\title{
References
}

1. Dai, S.; Zhao, L.; Peng, S.; Chou, C.L.; Wang, X.; Zhang, Y.; Li, D.; Sun, Y. Abundances and distribution of minerals and elements in high-alumina coal fly ash from the Jungar Power Plant, Inner Mongolia, China. Int. J. Coal Geol. 2010, 81, 320-332. [CrossRef]

2. Dai, S.; Finkelman, R.B. Coal as a promising source of critical elements: Progress and future prospects. Int. J. Coal Geol. 2018, 186, 155-164. [CrossRef]

3. Seredin, V.V.; Dai, S.; Sun, Y.; Chekryzhov, I.Y. Coal deposits as promising sources of rare metals for alternative power and energy-efficient technologies. Appl. Geochem. 2013, 31, 1-11. [CrossRef]

4. Dai, S.; Yan, X.; Ward, C.R.; Hower, J.C.; Zhao, L.; Wang, X.; Zhao, L.; Ren, D.; Finkelman, R.B. Valuable elements in Chinese coals: A review. Int. Geol. Rev. 2016, 60, 1-31.

5. Sun, Y.; Zhao, C.; Qin, S.; Xiao, L.; Li, Z.; Lin, M. Occurrence of some valuable elements in the unique 'high-aluminium coals' from the Jungar coalfield, China. Ore Geol. Rev. 2016, 72, 659-668. [CrossRef]

6. Hosteman, J.W.; Patterson, S.H.; Good, E.E. World Nonbauxite Aluminum Resources Excluding Alunite: USGS Professional Paper; United States Government Printing Office: Washington, DC, USA, 1990; pp. 38-42.

7. Su, S.Q.; Yang, J.; Ma, H.W.; Jiang, F.; Liu, Y.Q.; Li, G. Preparation of ultrafine aluminum hydroxide from coal fly ash by alkali dissolution process. Integr. Ferroelectr. 2011, 128, 155-162. [CrossRef]

8. Mehrotra, A.K.; Behle, L.A.; Raj Blshnol, P.; Svrcek, W.Y. High-temperature chlorination of coal ash in a fluidized bed. 1. Recovery of aluminum. Ind. Eng. Chem. Process Des. Dev. 1982, 21, 37-44. [CrossRef]

9. Wang, P.; Liu, H.; Zheng, F.; Liu, Y.; Kuang, G.; Deng, R.; Li, H. Extraction of aluminum from coal fly ash using pressurized sulfuric acid leaching with emphasis on optimization and mechanism. JOM 2021, 73, 2643-2651. [CrossRef]

10. Kumar, A.; Agrawal, S.; Dhawan, N. Processing of coal fly ash for the extraction of alumina values. J. Sustain. Metall. 2020, 6, 294-306. [CrossRef]

11. Gao, Y.; Liang, K.; Gou, Y.; Shen, W.; Cheng, F. Aluminum extraction technologies from high aluminum fly ash. Rev. Chem. Eng. 2021, 37, 885-906. [CrossRef]

12. Guo, Z.H. Study and industrialization development of one-step acid dissolution technology for alumina extraction from fly ash. Coal Eng. 2015, 7, 27-30.

13. Wang, B.; Chu, C.; Wei, H.; Zhang, L.; Ahmad, Z.; Wu, S.; Xie, B. Ameliorative effects of silicon fertilizer on soil bacterial community and pakchoi (Brassica chinensis L.) grown on soil contaminated with multiple heavy metals. Environ. Pollut. 2020, 267, 115411. [CrossRef]

14. Datnoff, L.E.; Snyder, G.H.; Deren, C.W. Influence of silicon fertilizer grades on blast and brown spot development and on rice. Plant Dis. 1992, 76, 1011-1013. [CrossRef]

15. Singh, T.; Singh, P.; Singh, A. Silicon significance in crop production: Special consideration to rice: An overview. J. Pharm. Innov. 2021, 10, 223-229. [CrossRef]

16. Matichenkov, V.V.; Bocharnikova, E.A.; Ammosova, J.A.M. The influence of silicon fertilizers on the plants and soils. In Proceedings of the International Scientific Forum “Butlerov Heritage-2015”, Kazan, Russia, 17 May 2015.

17. Cai, D.L.; Chen, C.Y.; Xiao, L.J. The influence of the silicon fertilizer on the Cd absorption by paddy. Areal Res. Dev. 2000, 4, 70-72.

18. Prakash, N.B.; Sandhya, T.S.; Sandhya, K.; Majumdar, S.; Pallavi, T.; Mohsina, A.; Kendra, G.K.V. Silicon in soil and plant nutrition: A decade of research at the University of Agricultural Sciences, Bangalore. Indian J. Fertil. 2021, 17, 140-154.

19. Rao, S.; Subha Lakshmi, C.; Tripathi, V.; Dubey, R.K.; Sudha Rani, Y.; Gangaiah, B. Fly ash and its utilization in Indian agriculture: Constraints and opportunities. In Circular Economy and Fly Ash Management; Springer: Singapore, 2020; pp. $27-46$.

20. Makabe-Sasaki, S.; Kakuda, K.I.; Sasaki, Y.; Ando, H. Effects of slag silicate fertilizer on silicon content of rice plants grown in paddy fields on the Shounai Plain, Yamagata, Japan. J. Soil Sci. Plant Nutr. 2014, 60, 708-721. [CrossRef]

21. Jiang, Y.; Zhou, H.; Gu, J.F.; Zeng, P.; Liao, B.H.; Xie, Y.H.; Ji, X.H. Combined amendment improves soil health and brown rice quality in paddy soils moderately and highly co-contaminated with Cd and As. Environ. Pollut. 2022, 295, 118590. [CrossRef] 
22. Li, N.; Feng, A.; Liu, N.; Jiang, Z.; Wei, S. Silicon application improved the yield and nutritional quality while reduced cadmium concentration in rice. Environ. Sci. Pollut. Res. 2020, 27, 20370-20379. [CrossRef]

23. Zhao, L. Alumina and silica extraction and byproduct development directly from chemical deashing of coals. Minerals 2022, 12, 179. [CrossRef]

24. Ma, S.H.; Xu, M.D.; Qi, Q.G.; Wang, X.H.; Ding, J.; Shi, J.P.; Che, L.M.G.; Zhao, Z.Q.; Zheng, S.L. A Soil Conditioner and its Preparation Method. Chinese Patent CN108239536A, 3 July 2018.

25. Ou, Y.; Ma, S.; Zhou, X.; Wang, X.; Shi, J.; Zhang, Y. The effect of a fly ash-based soil conditioner on corn and wheat yield and risk analysis of heavy metal contamination. Sustainability 2020, 12, 7281. [CrossRef]

26. Liang, Y.; Nikolic, M.; Bélanger, R.; Gong, H.; Song, A. History and introduction of silicon research. In Silicon in Agriculture; Springer: Dordrecht, The Netherlands, 2015; pp. 1-18. [CrossRef]

27. Xiao, Y.; Wang, B.; Liu, X.; Wang, X.; Zhao, L.; Yu, G. A study on sintering process of alumina extraction from fly ash. In Proceedings of the 9th National Circular Economy and Ecological Industry Symposium, Zhanjiang, China, 5 November 2014.

28. Yang, L.; Chi, J.; Wang, Y.; Chen, D. Comprehensive utilization of alumina extraction from fly ash. Clean Coal Technol. 2014, 20, 113-115.

29. Wang, X.; Wang, B.; Xiao, Y.; Liu, X.; Zhao, L.; Yu, G. Development of alumina \& silica-based high valuable products from fly ash In Proceedings of the 30th Annual International Pittsburgh Coal Conference, Beijing, China, 15 September 2013.

30. Han, C.; Liu, J. Method for Preparing Microporous Mineral Fertilizer from Silicates Rock Using Hydrothermal Chemical Reaction. Chinese Patent CN101450875, 10 June 2009.

31. Liu, S. Primary research of preparing potassium-silica compound fertilizer from potassium-rich rock by static hydrothermal reaction. Non-Met. Mines 2008, 31, 31-34.

32. Liu, S.; Han, C.; Liu, J. Study of K-feldspar and lime hydrothermal reaction: Phase and mechanism with reaction temperature and increasing Ca/Si ratio. Minerals 2019, 9, 46. [CrossRef]

33. Luo, Y.; Wu, Y. Utilization of by-product of alumina extraction from fly ash as silicate fertilizer. ChemRxiv 2021. Available online: https:/ / chemrxiv.org/engage/chemrxiv/article-details/60c755f7842e652c3edb43fd (accessed on 10 March 2021). [CrossRef]

34. Hu, P.; Zhang, Y.; Zhou, Y.; Ma, X.; Wang, X.; Tong, W.; Chu, P.K. Preparation and effectiveness of slow-release silicon fertilizer by sintering with iron ore tailings. Environ. Prog. Sustain. Energy 2015, 37, 1011-1019. [CrossRef]

35. Shoppert, A.; Valeev, D.; Loginova, I.; Chaikin, L. Complete extraction of amorphous aluminosilicate from coal fly ash by alkali leaching under atmospheric pressure. Metals 2020, 10, 1684. [CrossRef]

36. Cao, P.; Li, G.; Jiang, H.; Zhang, X.; Luo, J.; Rao, M.; Jiang, T. Extraction and value-added utilization of alumina from coal fly ash via one-step hydrothermal process followed by carbonation. J. Clean Prod. 2021, 323, 129174. [CrossRef]

37. Cao, P.; Li, G.; Luo, J.; Rao, M.; Jiang, H.; Peng, Z.; Jiang, T. Alkali-reinforced hydrothermal synthesis of lathy tobermorite fibers using mixture of coal fly ash and lime. Constr. Build. Mater. 2020, 238, 117655. [CrossRef]

38. GB/T 36207-2018; Fertilizers of Silicon, Calcium, Potassium Magnesium. China Standards Press: Beijing, China, 2018.

39. Meetei, T.T.; Devi, Y.B.; Chanu, T.T. Ion exchange: The most important chemical reaction on earth after photosynthesis. Int. Res. J. Pure Appl. Chem. 2020, 21, 31-42. [CrossRef]

40. Rahal, N.S.; Alhumairi, B.A.J. Modelling of soil cation exchange capacity for some soils of east gharaf lands from midMesopotamian plain (Wasit province/Iraq). Int. J. Environ. Sci. Technol. 2019, 16, 3183-3192. [CrossRef] 